\title{
A New Acetate Selective Polyamine Receptor Based on Anthracene and 4-Nitrophenyl Group
}

\author{
Sung Kyu Lee and Jongmin Kang* \\ Department of Chemistry, Sejong University, Seoul 143-747, Korea. *E-mail: kangjm@sejong.ac.kr \\ Received January 25, 2011, Accepted February 9, 2011
}

\begin{abstract}
A new amine receptor 2 utilizing anthracene and nitrophenyl group as signaling group was designed and synthesized. The receptor 2 only utilizes four amine N-H's and 9-anthracenyl hydrogen to bind anions. The receptor 2 can bind anions through hydrogen bonds with a selectivity of $\mathrm{CH}_{3} \mathrm{CO}_{2}^{-}>\mathrm{H}_{2} \mathrm{PO}_{4}^{-}>\mathrm{F}^{-}>\mathrm{C}_{6} \mathrm{H}_{5} \mathrm{CO}_{2}^{-}$ $>\mathrm{Cl}^{-}$in highly polar solvent such as DMSO without protonation of amine.
\end{abstract}

Key Words : Anion receptor, Polyamine receptor, Hydrogen bond

\section{Introduction}

The recognition and sensing of anions have become the focus of considerable attention because anions play an important role in biological, medical, environmental, and chemical sciences. ${ }^{1}$ Many chemical sensors follow the approach of the covalent attachment of signaling subunits and binding sites. ${ }^{2}$ Chromogenic or fluorogenic groups that are covalently linked to the receptor moiety as signaling subunits and multiple hydrogen-bonding interactions as binding sites have been frequently utilized. Hydrogen-bonding sites as binding sites typically used in chromogenic or fluorogenic chemosensors are ureas, ${ }^{3}$ thioureas, ${ }^{4}$ calix[4]pyrroles, ${ }^{5}$ amines, ${ }^{6}$ and amides. ${ }^{7}$ Among the binding units mentioned above, amines provide the weakest hydrogen bonds. Therefore, amine receptors have been protonated to provide electrostactic interactions in concert with hydrogen bonds. ${ }^{8}$ The measurements of binding processes are usually complicated by a complex series of protonation steps and multiple equilibria. The necessity of using an electrolyte to maintain constant ionic strength further complicates the situation, as extraneous cations and anions can interfere with binding of the targeted species. However, we envisioned that properly located multiple amine could be a good anion receptor without protonation despite of its weak hydrogen bonding ability.

Here we would like to report anthracene based amine receptor 2, which was found to be a selective receptor for acetate and dihydrogen phosphate in polar solvent such as DMSO without protonation. The binding phenomenon of

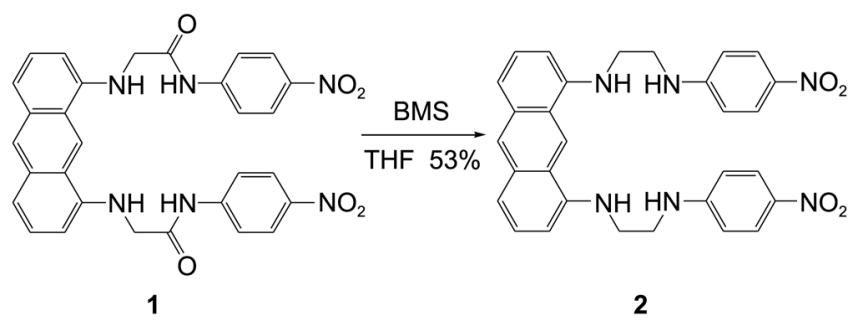

Scheme 1. The synthetic procedure for the anion receptor 2 . the receptor 2 was monitored by UV-vis spectra and ${ }^{1} \mathrm{H}$ NMR.

The receptor $\mathbf{2}$ was synthesized from the reduction reaction of the compound $\mathbf{1}$ with borane dimethyl sulfide complex in $53 \%$ yield $^{9}$ (Scheme 1 ).

Because of low solubility of the receptor 2 , we studied the binding phenomena in DMSO. The receptor $\mathbf{2}$ displayed strong absorption bands at $402 \mathrm{~nm}$ in DMSO. Figure 1 shows the family of spectra obtained over the course of the titration of solution $\mathbf{2}$ with tetrabutylammonium acetate in DMSO. As acetate ions were added to the $20 \mu \mathrm{M}$ solution of 2, $\lambda_{\max }$ showed bathochromic shift and isosbestic point at $404 \mathrm{~nm}$. The presence of the sharp isosbestic point indicates that only two species were present at equilibrium over the course of the titration experiment. The stoichiometry between the receptor 2 and acetate was determined by Job plot using ${ }^{1} \mathrm{H}$ NMR, which showed evident $1: 1$ stoichiometry (Fig. 2). A Benesi-Hildebrand plot $^{10}$ by use of change at 391 $\mathrm{nm}$ in UV-vis spectrum gave the association constants. The association constant calculated was $3.6 \times 10^{3} \mathrm{M}^{-1}$.

This phenomenon could be confirmed by a ${ }^{1} \mathrm{H}$ NMR titration. In DMSO- $d_{6}$, two amine N-H hydrogen peaks of receptor $\mathbf{2}$ showed downfield shifts upon addition of acetate ion. For example, one amine peak appearing at $7.49 \mathrm{ppm}$ showed downfield shift until $7.90 \mathrm{ppm}$ and the other amine peak appearing at $6.33 \mathrm{ppm}$ showed downfileld shift until $6.76 \mathrm{ppm}$, indicating that both amines participate in the binding event through hydrogen bonds. In addition, 9-H of

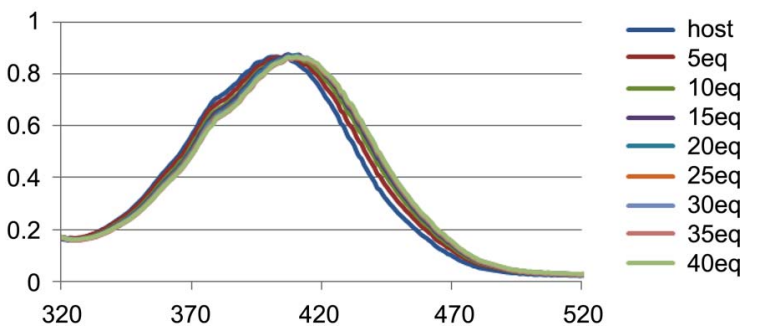

Figure 1. Family of UV-vis spectra recorded over the course of titration of $20 \mu \mathrm{M}$ DMSO solutions of the receptor 2 with the standard solution tetrabutylammonium acetate. 


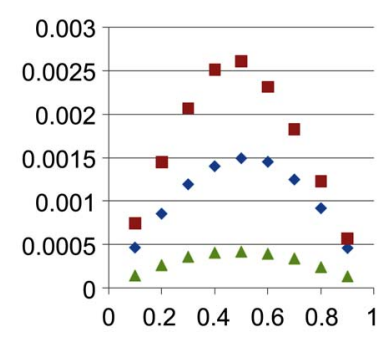

- Acetate

- Dihydrogen phosphate

$\triangle$ Chloride

Figure 2. The Job plots of $\mathbf{2}$ with tetrabutylammonium acetate, tetrabutylammonium dihydrogen phosphate and tetrabutylammonium chloride using ${ }^{1} \mathrm{H}$ NMR.
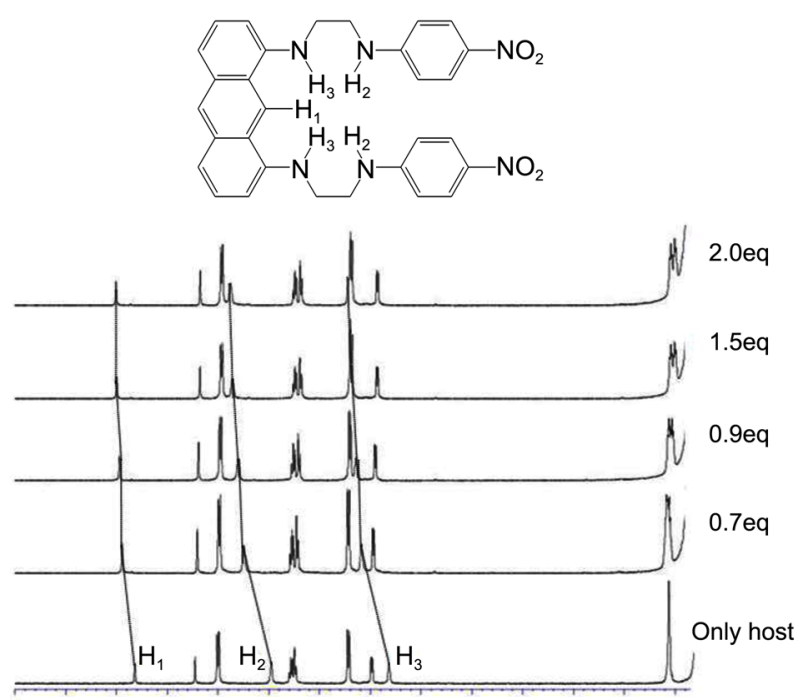

$\begin{array}{lllllllllllll}9.5 & 9.0 & 8.5 & 8.0 & 7.5 & 7.0 & 6.5 & 6.0 & 5.5 & 5.0 & 4.5 & 4.0 & \text { ppm }\end{array}$

Figure 3. ${ }^{1} \mathrm{H}$ NMR spectra of $2 \mathrm{mM}$ of the receptor 2 with increased amounts of tetrabutylammonium acetate (0-2.0 eq.) in DMSO- $d_{6}$.

the anthracene moiety appearing at 8.83 ppm showed downfield shift until $9.02 \mathrm{ppm}$, indicating that $9-\mathrm{H}$ of anthracene moiety also participates in hydrogen bonding with acetate. (Fig. 3) Many examples of receptors in which aromatic hydrogens participate in hydrogen bonding with anions have been reported. ${ }^{11}$ For titration, one of the amine N-H peaks was used. Analysis of chemical shift utilizing EQNMR ${ }^{12}$ gave the association constant of $4.5 \times 10^{3} \mathrm{M}^{-1}$, which is similar to the values obtained from UV-vis titrations.

With tetrabutylammonium dihydrogen phosphate, a similar phenomenon was observed. In UV-vis titration, $\lambda_{\max }$ of $\mathbf{2}$ showed bathochromic shift, spectra showed the isosbestic

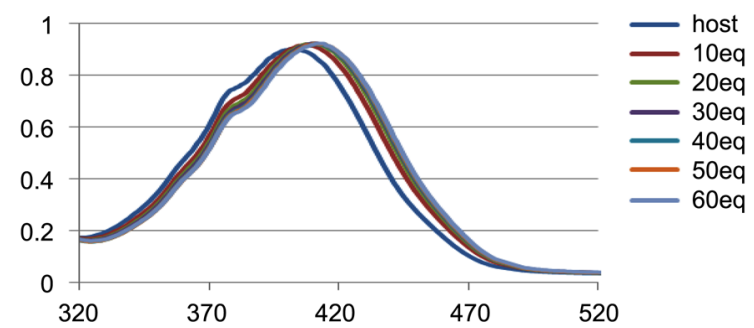

Figure 4. Family of UV-vis spectra recorded over the course of titration of $20 \mu \mathrm{M}$ DMSO solutions of the receptor 2 with the standard solution tetrabutylammonium dihydrogenphosphate.
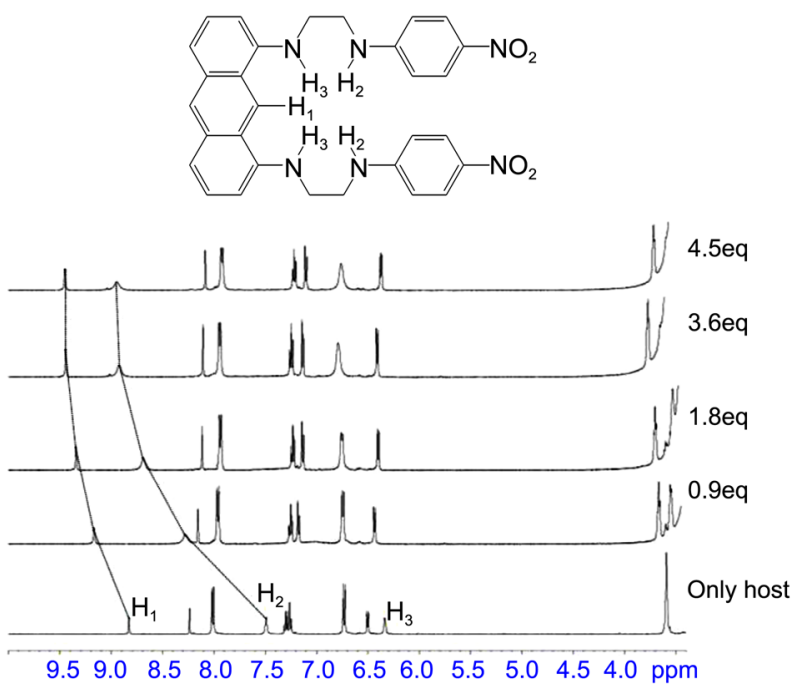

Figure 5. ${ }^{1} \mathrm{H}$ NMR spectra of $2 \mathrm{mM}$ of the receptor 2 with increased amounts of tetrabutylammonium dihydrogen phosphate $(0-4.5$ eq. $)$ in DMSO- $d_{6}$.

point at $404 \mathrm{~nm}$ and Job plot showed 1:1 stoichiometry again (Fig. 4). In addition, two amine N-H hydrogens and 9-H of the anthracene moiety showed downfield shifts again. However, the shift was more drastic than acetate ion. One of amine peak move from $7.49 \mathrm{ppm}$ to $8.95 \mathrm{ppm}$ and $9-\mathrm{H}$ of the anthracene moved from $8.83 \mathrm{ppm}$ to $9.45 \mathrm{ppm}$ with 4.5 equivalents of dihydrogen phosphate (Fig. 5). From these experiments, association constants for dihydrogen phosphate were calculated as $2.0 \times 10^{3}$ and $2.3 \times 10^{3} \mathrm{M}^{-1}$ from the UVvis and ${ }^{1} \mathrm{H}$ NMR titrations, respectively.

We also investigated association constants of other anions. The results are summarized in Table 1. The receptor 2 interacts with fluoride, chloride and benzoate at the concentration we investigated. Bromide, iodide, hydrogensulfate, perchlorate and nitrate did not bind with the receptor 2. Probably the basicities these anions are too weak to bind with amine receptor $\mathbf{2}$. Due to weak acidity of the receptor $\mathbf{2}$, deprotonation was not observed.

In summary, we have developed a new anion receptor 2 utilizing anthracene and nitrophenyl group as signaling group. The receptor 2 only utilizes four amine N-H's and 9anthracenyl hydrogen to bind anions. The receptor $\mathbf{2}$ can bind anions through hydrogen bonds with a selectivity of $\mathrm{CH}_{3} \mathrm{CO}_{2}^{-}>\mathrm{H}_{2} \mathrm{PO}_{4}^{-}>\mathrm{F}^{-}>\mathrm{C}_{6} \mathrm{H}_{5} \mathrm{CO}_{2}^{-}>\mathrm{Cl}^{-}$in highly polar

Table 1. The association constants $\left(\mathrm{M}^{-1}\right)$ of the receptor 2 with various anions in DMSO

\begin{tabular}{ccc}
\hline \multirow{2}{*}{ Anion } & \multicolumn{2}{c}{$\mathbf{2}$} \\
\cline { 2 - 3 } & $\mathrm{UV}$ & $\mathrm{NMR}$ \\
\hline $\mathrm{CH}_{3} \mathrm{CO}_{2}^{-}$ & $3.6 \times 10^{3}$ & $4.5 \times 10^{3}$ \\
$\mathrm{H}_{2} \mathrm{PO}_{4}^{-}$ & $2.0 \times 10^{3}$ & $2.2 \times 10^{3}$ \\
$\mathrm{~F}^{-}$ & $8.3 \times 10^{2}$ & $6.9 \times 10^{2}$ \\
$\mathrm{C}_{6} \mathrm{H}_{5} \mathrm{CO}_{2}^{-}$ & $2.0 \times 10^{2}$ & $2.3 \times 10^{2}$ \\
$\mathrm{Cl}^{-}$ & $1.8 \times 10^{2}$ & $2.3 \times 10^{2}$ \\
\hline
\end{tabular}


solvent without protonation of amine.

Acknowledgments. This research was supported by Basic Science Research Program through the National Research Foundation of Korea(NRF) funded by the Ministry of Education, Science and Technology (2010-0021333).

This work was supported by the Human Resources Development of the Korea Institute of Energy Technology Evaluation and Planning (KETEP) grant funded by the Korea government Ministry of Knowledge Economy (No. 20100092).

\section{References}

1. (a) Haugland, R. P. The Handbook. A Guide to Fluorescent Probes and Labeling Technologies, 10th ed.; Molecular Probes Inc.: Eugene, OR, 2005. (b) Anion Sensing; Stibor, I., Ed.; SpringerVerlag: Berlin 2005. (c) Lhoták, P. Top. Curr. Chem. 2005, 255, 65. (d) Matthews, S. E.; Beer, P. D. Supramol. Chem. 2005, 17, 411. (e) Martinez-Manez, R.; Sancenon, F. Chem. Rev. 2003, 103, 4419. (f) Beer, P. D.; Gale, P. A. Angew. Chem., Int. Ed. 2001, 40, 486. (g) Haryley, J. H.; James, T. D.; Ward, C. J. J. Chem. Soc., Parkin Trans. 1 2000. 19, 3155. (h) de Silva, A. P.; Nimal Gunaratne, H. Q.; Gunnlaugsson, T.; Huxley, A. J. M.; McCoy, C. P.; Rademacher, J. T.; Rice, T. E. Chem. Rev. 1997, 97, 1515. (i) Fluorescent Chemosensors for Ion and Molecule Recognition; Czarnik, A. W., Ed.; American Chemical Society Books: Washington, DC, 1993.

2. (a) Kwon, J. Y.; Jang, Y. J.; Kim, S. K.; Lee, K.-H.; Kim, J. S.; Yoon, J. J. Org. Chem. 2004, 69, 5155. (b) Kim, S. K.; Singh, N. J.; Kim, S. J.; Kim, H. G.; Kim, J. K.; Lee, J. W.; Kim, K. S.; Yoon, J. Org. Lett. 2003, 5, 2083.

3. (a) Boiocchi, M.; Boca, L. D.; Gomez, D. E.; Fabbrizzi, L.; Licchelli, M.; Monzani, E. J. Am. Chem. Soc. 2004, 126, 16507. (b) Werner, F.; Schneider, H.- J. Helv. Chim. Acta 2000, 83, 465. (c) Snellink-Ruel, B. H. M.; Antonisse, M. M. G.; Engbersen, J. F. J.; Timmerman, P.; Reinhoudt, D. N. Eur. J. Org. Chem. 2000, 165. (d) Kwon, J. Y.; Jang, Y. J.; Kim, S. K.; Lee, K. H.; Kim, J. S.; Yoon, J. Y. J. Org. Chem. 2004, 69, 5155. (e) Ayling, A. J.; Perez-Payan, M. N.; Davis, A. P. J. Am. Chem. Soc. 2001, 123, 12716.

4. (a) Gunnlaugsson, T.; Davis, A. P.; Hussey, G. M.; Tierney, J.; Glynn, M. Org. Biomol. Chem. 2004, 2, 1856. (b) Gunnlaugsson, T.; Davis, A. P.; O’Brien, J. E.; Glynn, M. Org. Biomol. Chem. 2005, 3, 48. (c) Kim, S. K.; Singh, N. J.; Kim, S. J.; Swamy, K. M. K.; Kim, S. H.; Lee, K. H.; Kim, K. S.; Yoon, J. Tetrahedron 2005, 61, 4545. (d) Bühlmann, P.; Nishizawa, S.; Xiao, K. P.; Umezawa, Y. Tetrahedron 1997, 53, 1647. (e) Benito, J. M.; Gómez-García, M.; Blanco, J. L. J.; Mellet, C. O.; Fernández, J. M. G. J. Org.
Chem. 2001, 66, 1366. (f) Dryfe, R. A. W.; Hill, S. S.; Davis, A. P.; Joos, J.-B.; Roberts, E. P. L. Org. Biomol. Chem. 2004, 2, 2716. (g) Fan, E.; Van Arman, S. A.; Kincaid, S.; Hamilton, A. D. J. Am. Chem. Soc. 1993, 115, 369.

5. (a) Panda, P. K.; Lee, C.-H. J. Org. Chem. 2005, 70, 3148. (b) Sessler, J. L.; Davis, J. M. Acc. Chem. Res. 2001, 34, 989.

6. Wichmann, K.; Antonioli, B.; Söhnel, T.; Wenzel, M.; Gloe, K.; Gloe. K., Price, J. R.; Lindoy, L. F.; Blake, A. J.; Schröder, M. Coordination Chem. Rev. 2006, 250, 2987.

7. (a) Chmielewski, M. J.; Jurczak, J. Chem. Eur. J. 2005, 11, 6080. (b) Bao, X.; Zhou, Y. Sensors and Actuators B: Chem. 2010, 147, 434. (c) Kang, S. O.; Linares, J. M.; Powell, D.; VanderVelde, D.; Bowman-James, K. J. Am Chem. Soc. 2003, 125, 10152. (d) Kondo, S.-I.; Hiraoka, Y.; Kurumatani, N.; Yano, Y. Chem. Commun. 2005, 1720. (e) Xie, H.; Yi, S.; Wu, S. J. Chem. Soc., Perkin Trans. 2 1999, 2751. (f) Sessler, J. L.; An, D.; Cho, W.-S.; Lynch, V.; Marquez, M. Chem. Eur. J. 2005, 11, 2001. (g) Chellappan, K.; Singh, N. J.; Hwang, I.-C.; Lee, J. W.; Kim, K. S. Angew. Chem. Int. Ed. 2005, 44, 2899. (h) Nishiyabu, R.; Anzenbacher, P., Jr. J. Am. Chem. Soc. 2005, 127, 8270.

8. (a) Wichmann, K.; Antonoli, B.; Söhnel, T.; Wenzel, M.; Gloe, K.; Gloe, K.; Price, J. R.; Lindoy, L. F.; Blake, A. J.; Schröder, M. Coordination. Chem. Rev. 2006, 250, 2987. (b) Liinares, J. M.; Powell, D.; Bowman-James, K. Coordination. Chem. Rev. 2003, $240,57$.

9. Synthesis of compound 2: To a solution of the compound $\mathbf{1}(200$ $\mathrm{mg}, 0.35 \mathrm{mmol})$ in dried THF $(10 \mathrm{~mL})$ under nitrogen at $0{ }^{\circ} \mathrm{C}$ was added borane dimethyl sulfide $(166 \mu \mathrm{L}, 1.75 \mathrm{mmol})$ and stirred for $30 \mathrm{~min}$. Then the reaction mixture was refluxed for 8 hours. The reaction mixture was cooled to room temperature. After distilled water $(10 \mathrm{~mL})$ was added to this reaction mixture, it was stirred for 1 hour. Filtration of the precipitated solid and recrystallization using acetone and hexane gave the desired product $\left(100 \mathrm{mg}\right.$ ) in $53 \%$ yield. ${ }^{1} \mathrm{H}$ NMR $\left(500 \mathrm{MHz}, \mathrm{DMSO}-d_{6}\right) \delta$ $8.83(\mathrm{~s}, 1 \mathrm{H}), 8.24(\mathrm{~s}, 1 \mathrm{H}), 8.02(\mathrm{~d}, 4 \mathrm{H}, J=9.0 \mathrm{~Hz}), 7.49(\mathrm{~s}, 2 \mathrm{H})$, $7.28(\mathrm{~m}, 4 \mathrm{H}), 6.74(\mathrm{~d}, 4 \mathrm{H}, J=9.0 \mathrm{~Hz}), 6.51(\mathrm{~d}, 2 \mathrm{H}, J=7.0 \mathrm{~Hz})$, $6.33(\mathrm{~s}, 2 \mathrm{H}), 3.59(\mathrm{~m}, 8 \mathrm{H}){ }^{13} \mathrm{C}$ NMR $\left(500 \mathrm{MHz}\right.$, DMSO- $\left.d_{6}\right) \delta$ $154.5,143.6,135.8,132.1,126.67,126.3,125.5,121.7,115.4$, 113.7, 100.3, 42.3, 41.2 FAB MS $m / z\left(\mathrm{M}^{+}\right)$: calcd, 536.22, found, 536.27

10. Benesi, H.; Hildebrand, H. J. Am. Chem. Soc. 1949, 71, 2703.

11. (a) Jeong, K.-S.; Cho, Y. L. Tetrahedron Lett. 1997, 38, 3279. (b) Gale, P. A.; Hursthouse, M. B.; Light, M. E.; Sessler, J. L.; Warriner, C. N.; Zimmerman, R. S. Tetrahedron Lett. 2001, 42, 6759. (c) Abouderbala, L. O.; Belcher, W. J.; Boutelle, M. G.; Cragg, P. J.; Steed, J. W.; Turner, D. R.; Wallace, K. J. Proc. Natl. Acad. Sci. USA. 2002, 99, 5001. (d) Yoon, D.-W.; Hwang, H.; Lee, C.-H. Angew. Chem. Int. Ed. 2002, 41, 1757. (e) Kwon, J. Y; Jang, Y. J.; Kim, S. K.; Lee, K.-H.; Kim, J. S.; Yoon, J. J. Org. Chem. 2004, 69, 5155. (f) In, S.; Cho, S. J.; Lee, K. H.; Kang, J. Organic Lett. 2005, 7(18), 3993.

12. Hynes, M. J. J. Chem. Soc., Dalton Trans. 1993, 311. 